\title{
Potential water supply of a small reservoir and alluvial aquifer system in southern Zimbabwe
}

\author{
W. de Hamer ${ }^{\mathrm{a}, *}$, D. Love ${ }^{\mathrm{b}, \mathrm{c}}$, R. Owen ${ }^{\mathrm{d}}$, M.J. Booij ${ }^{\mathrm{a}}$, A.Y. Hoekstra ${ }^{\mathrm{a}}$ \\ ${ }^{a}$ Department of Water Engineering and Management, University of Twente, P.O. Box 217, 7500 AE, Enschede, The Netherlands \\ ${ }^{\mathrm{b}}$ WaterNet, P.O. Box MP600, Mount Pleasant, Harare, Zimbabwe \\ c ICRISAT Bulawayo, Matopos Research Station, P.O. Box 776 Bulawayo, Zimbabwe \\ ${ }^{\mathrm{d}}$ Mineral Resources Centre, University of Zimbabwe, P.O. MP167, Mount Pleasant, Harare, Zimbabwe
}

\section{A R T I C L E I N F O}

Available online 10 July 2008

Keywords:

Alluvial aquifer

MODFLOW

Rainfall-runoff relation

Potential water supply

\begin{abstract}
A B S T R A C T
Groundwater use by accessing alluvial aquifers of non-perennial rivers can be an important additional water resource in the semi-arid region of southern Zimbabwe. The research objective of the study was to calculate the potential water supply for the upper-Mnyabezi catchment under current conditions and after implementation of two storage capacity measures. These measures are heightening the spillway of the 'Mnyabezi 27' dam and constructing a sand storage dam in the alluvial aquifer of the Mnyabezi River. The upper-Mnyabezi catchment covers approximately $22 \mathrm{~km}^{2}$ and is a tributary of the Thuli River in southern Zimbabwe. Three coupled models are used to simulate the hydrological processes in the Mnyabezi catchment. The first is a rainfall-runoff model, based on the SCS-method. The second is a spreadsheetbased model of the water balance of the reservoir. The third is the finite difference groundwater model MODFLOW used to simulate the water balance of the alluvial aquifer. The potential water supply in the Mnyabezi catchment under current conditions ranges from $2107 \mathrm{~m}^{3}$ (5.7 months) in a dry year to $3162 \mathrm{~m}^{3}$ ( 8.7 months) in a wet year. The maximum period of water supply after implementation of the storage capacity measures in a dry year is $2776 \mathrm{~m}^{3}$ (8.4 months) and in a wet year the amount is $3617 \mathrm{~m}^{3}(10.8$ months). The sand storage dam can only be used as an additional water resource, because the storage capacity of the alluvial aquifer is small. However, when an ephemeral river is underlain by a larger alluvial aquifer, a sand storage dam is a promising way of water supply for smallholder farmers in southern Zimbabwe.
\end{abstract}

(C) 2008 Elsevier Ltd. All rights reserved.

\section{Introduction}

The variability of rainfall coupled with extended duration of droughts is threatening food and water security in sub-Saharan Africa in general and the southern Africa in particular. Local storage of water using low cost rainwater harvesting technologies is seen as an important step in ensuring water availability and food security for resource poor smaller-holder farmers.

Access to irrigation water for smallholder farmers is limited in the Limpopo basin (Love et al., 2006). In the semi-arid regions of Zimbabwe, artificial surface reservoirs have been designed to meet the domestic and agricultural (mainly livestock) water requirements of smallholder farmers in dry periods. However, most of the smaller reservoirs dry out within half a year after the main rainy season. In this situation, groundwater use by accessing alluvial aquifers of non-perennial rivers can be an important additional water resource (Owen and Dahlin, 2005; Moyce et al., 2006). Barker and

\footnotetext{
* Corresponding author.

E-mail address: w.dehamer@alumnus.utwente.nl (W. de Hamer).
}

Molle (2004) describe an alluvial aquifer as a groundwater unit, generally unconfined, hosted in laterally discontinuous layers of sand, silt and clay and deposited by a river in a river channel, banks or flood plain. Alluvial aquifers in large perennial rivers, like the Mzingwane River in Zimbabwe, meet agricultural and domestic water requirements in some cases in southern Africa (Seely et al., 2003; Love et al, 2007). Owen and Dahlin (2005) and Moyce et al. (2006) calculated that the groundwater storage of alluvial aquifer of the Mzingwane River has a large potential water supply. However, most smallholder farmers in semi-arid regions live near to smaller non-perennial rivers that make research to groundwater resources in these smaller alluvial aquifers interesting.

This study focuses on the hydrological processes occurring in the upper-Mnyabezi catchment, which is a tributary of the Thuli River in southern Zimbabwe. Water is stored in the reservoir of the 'Mnyabezi 27' dam and in the alluvial aquifer of the Mnyabezi River. These two ways of water storage ensure water availability during the dry season for plants, animals and people, but is still not enough to supply water the whole year round. The research objective was to calculate the potential water supply for the upperMnyabezi catchment in the semi-arid region of southern Zimbabwe 
for current conditions and after implementation of two possible storage capacity interventions. These interventions were (i) heightening the spillway of the 'Mnyabezi 27' dam and (ii) constructing a sand storage dam in the alluvial aquifer of the Mnyabezi River. Sand storage dams store water in the alluvial sediments, which are accumulated upstream of the dam (Hanson, 1987; Mansell and Hussey, 2005). The sediment becomes saturated after a river flow event.

\section{Study area}

The river upstream of the 'Mnyabezi 27' dam is about $8 \mathrm{~km}$ long and the catchment area covers approximately $22 \mathrm{~km}^{2}$. The study area also includes the alluvial aquifer for a length of $1.0 \mathrm{~km}$ downstream of the dam. The soil of the Mnyabezi catchment area consists of sandy loam and the underlying layer consists of weathered granite (Matura et al., 2007). The soil layer is shallow to moderately deep and is on average $0.5 \mathrm{~m}$ thick (Moyo, 2001). The land use is a mixture of agricultural fields (4.0\%), farmsteads (0.5\%) and sparsely wooded degraded rangeland (95.5\%) where cattle graze.

The main use of the highly silted reservoir is for drinking by cattle. The local community is planning to build a new spillway. The difference between the bottom of the reservoir and the top of the spillway is $0.73 \mathrm{~m}$ (for the new spillway it is $1.00 \mathrm{~m}$ ). When the reservoir is full, it covers an area of 1.54 ha and reaches a total volume of $5600 \mathrm{~m}^{3}$. Every year the reservoir dries out during the dry period of the year. The Mnyabezi River is highly ephemeral, which means it only flows during and shortly after a heavy rain event. The alluvial aquifer downstream of the dam has a width varying from 9 to $11 \mathrm{~m}$, a maximum depth of $1.4 \mathrm{~m}$ and a slope of $0.28 \%$. Physical probing done during field visits indicate some locally thin clay layers at several depths, but the main material is fine to medium sand (hydraulic conductivity; $k \approx 69 \mathrm{mday}^{-1}$ ).

\section{Methods}

The first paragraph in this section describes the field measurements carried out during the March-May 2007. The second paragraph elaborates on the modelling of the hydrological conditions in the Mnyabezi catchment for a dry, normal and wet year. The last paragraph describes the calibration method using the measured data.

\subsection{Field measurements}

Alluvial aquifers in the arid regions recharge relatively fast (Gorgens and Boroto, 1997; Moyce et al., 2006). These short hydrological processes require a daily time step for the modeling process, which in turn requires daily input data. Hydrological variables (like precipitation, evapotranspiration, water abstractions of cattle, water level in the reservoir and the water table in the alluvial aquifer) were measured daily between March and May 2007. Several hydro(geo)logical parameters (like hydraulic conductivity, hydrological soil group, land use, land treatment, dimensions of the reservoir and the profile of the alluvial aquifer) were measured on a once-off basis.

\subsection{Modeling}

In this study, three coupled models were used to simulate the hydrological processes in the Mnyabezi catchment (Fig. 2 visualizes the flows between the models). Every year the variability of rainfall events and the amount of rainfall differs. The aim of the study was to calculate the potential water supply during a typical dry year, year with about average rainfall, and a wet year. Surface and groundwater runoff in the study area were simulated for these three typical years, where a year starts at the beginning of the main rainy season (1st of November) and ends at the end of the dry season (31st of October). Three typical years have been selected from the daily rainfall records of the Thuli Estate meteorological station between 1987 and 2000. Note that in (semi-)arid regions, the variability of rainfall events during a year mainly determines if a year will be typified as dry, normal or wet in water supply terms (Butterworth et al., 1999). A typical dry year was ' $88 /$ '9 (259.2 mm), a normal year was ‘97/'98 (331.9 mm) and wet year was ‘96/’97 (568.4 mm).

A simple rainfall-runoff model, based on the SCS-method (USDA-SCS, 1972, 1986), has been used to calculate the surface water runoff caused by precipitation. The method relates the

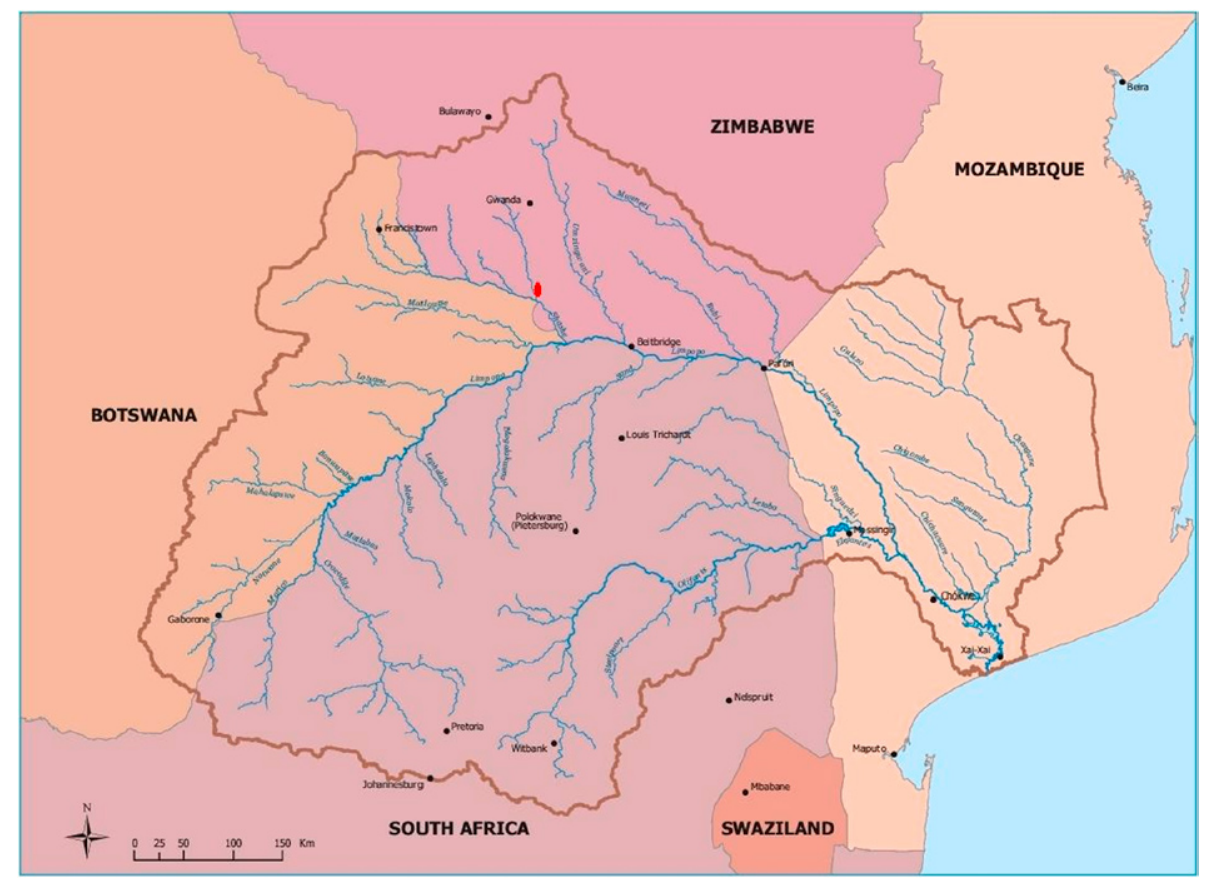

Fig. 1. Location of Mnyabezi River in the northern Limpopo Basin. Inset: location in southern Africa. 
discharge $(Q)$ to total rainfall $(P)$ and storage capacity via an empirical relation. The method is discussed further elsewhere (De Hamer et al., 2007).

A spreadsheet-based reservoir model has been used to simulate the water level in the artificial surface reservoir of the 'Mnyabezi 27' dam. The runoff from the Mnyabezi catchment, calculated by the rainfall-runoff model, forms the inflow variable for the reservoir model. The model also incorporates the variables, namely (i) direct recharge by precipitation, (ii) open water evaporation (iii) abstraction by cattle, and (iv) seepage. Groundwater flow in these semi-arid regions into the reservoir is usually negligible (Barnes et al., 1994; Sandstrom, 1997). The potential water supply of the reservoir is the summation of the daily consumption of water by cattle. Dam overflow occurs when the water level in the reservoir is higher than the height of the spillway. We have simulated the water level and the potential water supply under current conditions and under the scenario with a heightened spillway.

The finite difference groundwater model MODFLOW (McDonald and Harbaugh 1988; Harbaugh, 2005) has been used to simulate daily groundwater levels in the alluvial aquifer downstream of the dam. The model consists of three layers; a top layer $(0.7 \mathrm{~m})$ representing the soil, a second layer representing the alluvial aquifer and a third layer representing the underlying granite layer. The general model domain is $230 \mathrm{~m}$ in width and $1000 \mathrm{~m}$ in length with a horizontal resolution of $5 \times 5 \mathrm{~m}$. Because the main hydrogeological processes occur in the alluvial aquifer and adjacent river banks, these areas have a higher resolution of $2 \times 5 \mathrm{~m}$. The alluvial aquifer is modelled as a rectangular shape with a depth of $0.9 \mathrm{~m}$, a width of $10 \mathrm{~m}$ and a slope of $0.28 \%$. In the MODFLOW model, hydrogeological characteristics, like hydraulic conductivity, specific yield and porosity, have to be assigned to every layer separately. Due to the loose structure of the alluvial material, the hydrogeological parameters have been assumed constant in all directions. This is not true for granite due to its complex rock structure. In the Mnyabezi catchment, the granites are altered and best described as weathered older gneisses (Matura et al., 2007). Normally, fresh granite has a very low primary porosity, but granite always has a secondary porosity due to weathering and an interconnected system of fractures, fissures and joints, which allows the flow and storage of groundwater (Todd, 1980). Due to this secondary porosity the hydraulic conductivity, porosity and specific yield of granite are non-homogeneous. Nevertheless, MODFLOW calculates with average values. We have simulated the water balance and the potential water supply of the alluvial aquifer under current conditions and under scenario of a sand storage dam.

\subsection{Calibration}

Since the Mnyabezi River is ungauged, it was necessary to calibrate the rainfall-runoff model in combination with the reservoir model. By measuring the increase in water level of the reservoir after a rain event, the amount of river inflow was calculated. This value was used to calibrate the rainfall-runoff model. For the rainfall-runoff model the initial abstraction was used as the fitting parameter for the calibration of the model. The initial abstraction $\left(I_{a}\right)$ is difficult to determine in (semi-)arid regions due to surface crust forming (FAO, 1991) and the variable transmission losses into the alluvial aquifer (Anderson, 1997). These features make the normal assumption: $I_{a}=20 \%$ of the potential retention $(S)$ not valid (USDA-SCS, 1972). Studies in southern Africa have used percentages of $10 \%$ and less (Schulze et al., 1993; Hranova, 2006). To obtain the best fit, the initial abstraction was changed between $5.0 \%$ and $15.0 \%$ of actual retention. The seepage was used as the fitting parameter for the calibration of the reservoir model. The seepage was varied between 0.0 and $1.0 \mathrm{mmday}^{-1}$. The efficiency coefficient developed by Nash and Sutcliffe (1970), resulted in a value of 0.99 , using an initial abstraction $\left(I_{a}\right)$ of $7.6 \%$ of actual retention and a seepage of $0.0 \mathrm{mmday}^{-1}$.

The observed and calculated groundwater levels in the alluvial aquifer have been used to calibrate the MODFLOW model. The groundwater level measurements resulted in a drying period from the alluvial aquifer of 20 days after a dam overflow event. This relatively fast depletion time is caused by heavy weathering conditions of the underlying granite layer. Due to lack of a good method to determine the values for the hydraulic conductivity, specific yield and effective porosity for weathered granite, these parameters were used as fitting parameters for the calibration of the model. The hydraulic conductivity for weathered granite ranges between 0.5 and 1.4 may $^{-1}$ (Morris and Johnson, 1967; Davis, 1969; Shaw, 1994). The specific yield for weathered granite ranges between 0.01 and 0.05 and the effective porosity ranges between 0.05 and 0.15 (Todd, 1980; Rushton and Weller, 1985). The hydraulic conductivity and the specific yield were manually varied between the above ranges to make a best fit. Since the sensitivity of the porosity in the model was low, this value was assumed constant at a value 0.08 . After manual calibration, the PEST-module (automatic calibration module) of the MODFLOW model fine-tuned the calibration. A correlation coefficient of 0.99 was obtained using a value of $0.55 \mathrm{~m} \mathrm{day}^{-1}$ for the hydraulic conductivity, and 0.03 for the specific yield.

\section{Results}

The first paragraph of this section describes the potential water supply of the reservoir including the scenario after heightening the spillway. The second paragraph presents the results of the potential water supply of the alluvial aquifer under current conditions and after implementing a sand storage dam.

\subsection{Dam reservoir}

The reservoir model has been used to analyze the hydrological characteristics of the reservoir during a dry year ('89/'99), a normal

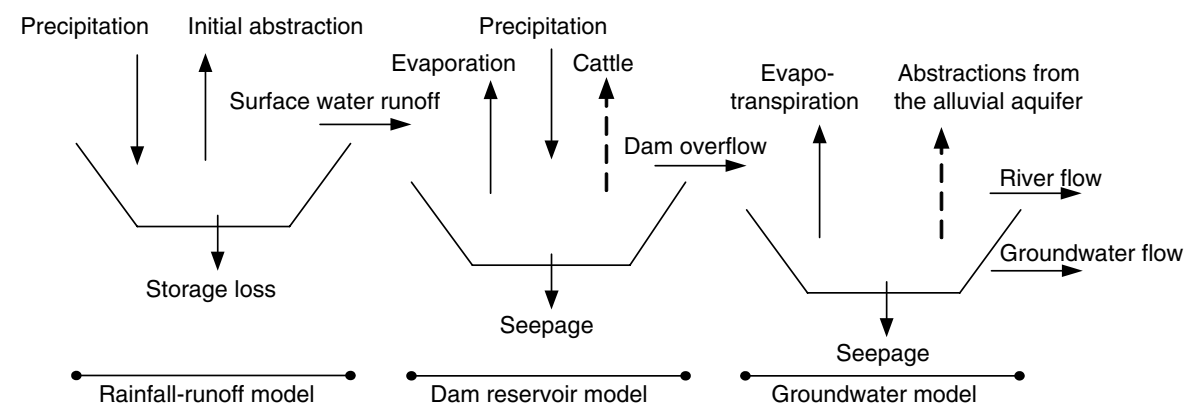

Fig. 2. Schematization of flows between hydrological models; the dashed lines represent the potential water supply. 

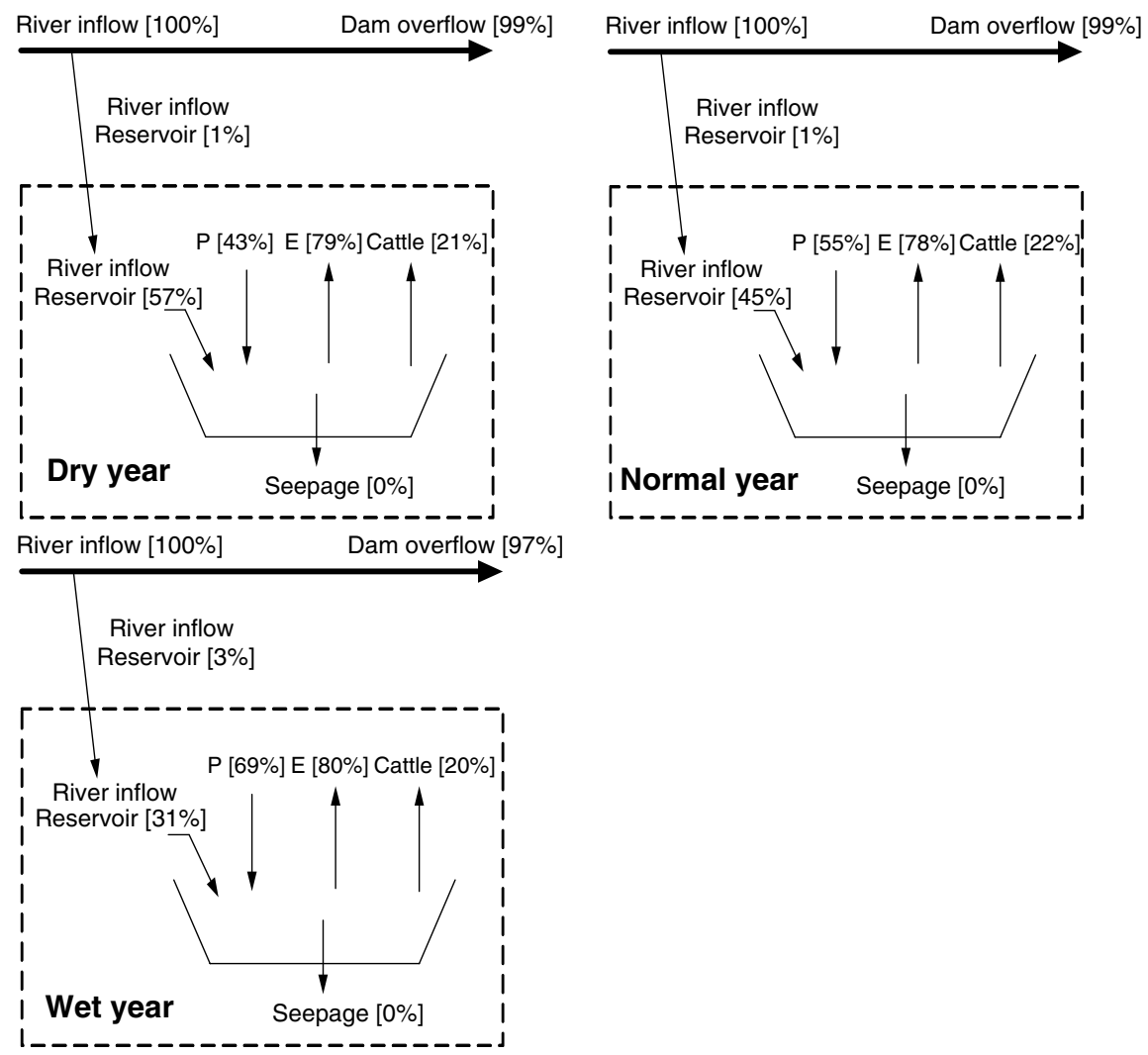

Fig. 3. Water balance results of the Mnyabezi reservoir for a dry, normal and wet year.

year ('97/'98) and a wet year ('96/'97). The water balance results of the reservoir for these three years are presented in Fig. 3. The results show approximately the same proportions between natural losses; the evaporation loss is $79 \%$, cattle abstractions count for $21 \%$ and the seepage losses are negligible. Of course, this means that the total amount of evaporation and abstractions by cattle increases for wetter years in comparison to drier years. Based on the model outputs, it is clear that the differences in reservoir inflow are usually caused by the different rainfall patterns; in drier years, the rainfall is mainly concentrated during a few heavy rain events and in wetter years, the rain events are less heavy, but more frequent and dispersed over a longer period.

Fig. 4 shows the calculated water levels in the reservoir under the current situation and under the scenario with a heightened spillway. The drying period of the reservoir is approximately 4.5 months (after the last dam overflow event and without rain events during that period). Fig. $4 \mathrm{a}$ and $\mathrm{b}$ show that the reservoir stores water for approximately five weeks longer after heightening the spillway to a height of $1.0 \mathrm{~m}$. During the wet year of '96/'97 (Fig. 4c) the increase in drying period is only two weeks, which is caused by the rainfall event in the beginning of April.

The reservoir model has been used to calculate the amount of potential water supply under the current situation and under the scenario with a heightened spillway (see Table 1). The potential water supply is the summation of the daily water consumption by cattle when the reservoir contains water. The period of available water in the reservoir was calculated as well.

\subsection{Alluvial aquifer}

The MODFLOW model has been used to analyze the hydrological characteristics of the alluvial aquifer. An analysis was made for the natural losses in the period after a single river flow event. The total amount of water that can be stored in the alluvial aquifer is $630 \mathrm{~m}^{3}$ (over the section of $200 \mathrm{~m}$, which is used as the design criterion of the sand storage dam). The calculated total amount of evapotranspiration loss is $88 \mathrm{~m}^{3}$ (14\%) and the seepage loss to the underlying granite layer is $529 \mathrm{~m}^{3}$ (86\%). The flow through the alluvial aquifer is $13 \mathrm{~m}^{3}(2 \%)$, which is small compared to the other flows. An overview of the water balance is shown in Fig. 5. The same analysis was done for the situation with a sand storage dam constructed in the alluvial aquifer. Due to the heavy weathering conditions of the underlying granite the seepage loss is very large in the natural situation. It should be noted that the model simulated an impermeable layer (clay, dolomite, fresh granite) on the bottom of the sand storage dam, because sand storage dams are always constructed above such layers (based on field observations in southern Zimbabwe). The total amount that can be stored in the sand storage dam is $980 \mathrm{~m}^{3}$. The maximum water abstraction from the sand storage dam equals $603 \mathrm{~m}^{3}(62 \%)$ and the only natural loss is due to evapotranspiration (38\%). The total evapotranspiration loss becomes constant, because the evapotranspiration becomes negligible when the water table recedes $0.9 \mathrm{~m}$ below the surface of the alluvial aquifer (Wipplinger, 1958; Nord, 1985; Borst and DeHaas; 2006).

For the calculation of the potential water supply the abstractions from the sand storage dam were held constant $7.0 \mathrm{~m}^{3} \mathrm{day}^{-1}$. This is approximately the amount of daily domestic water use plus the water needed to maintain the small gardens surrounding the reservoir. An advantage of a sand storage dam is that water does not have to be used immediately. However, the longer water is stored behind the dam, the larger the amount of natural losses becomes. Fig. 6 provides insight into the relation between the potential water supply and the start of abstractions after the last river flow event for the sand storage dam in the alluvial aquifer of the Mnyabezi River. 

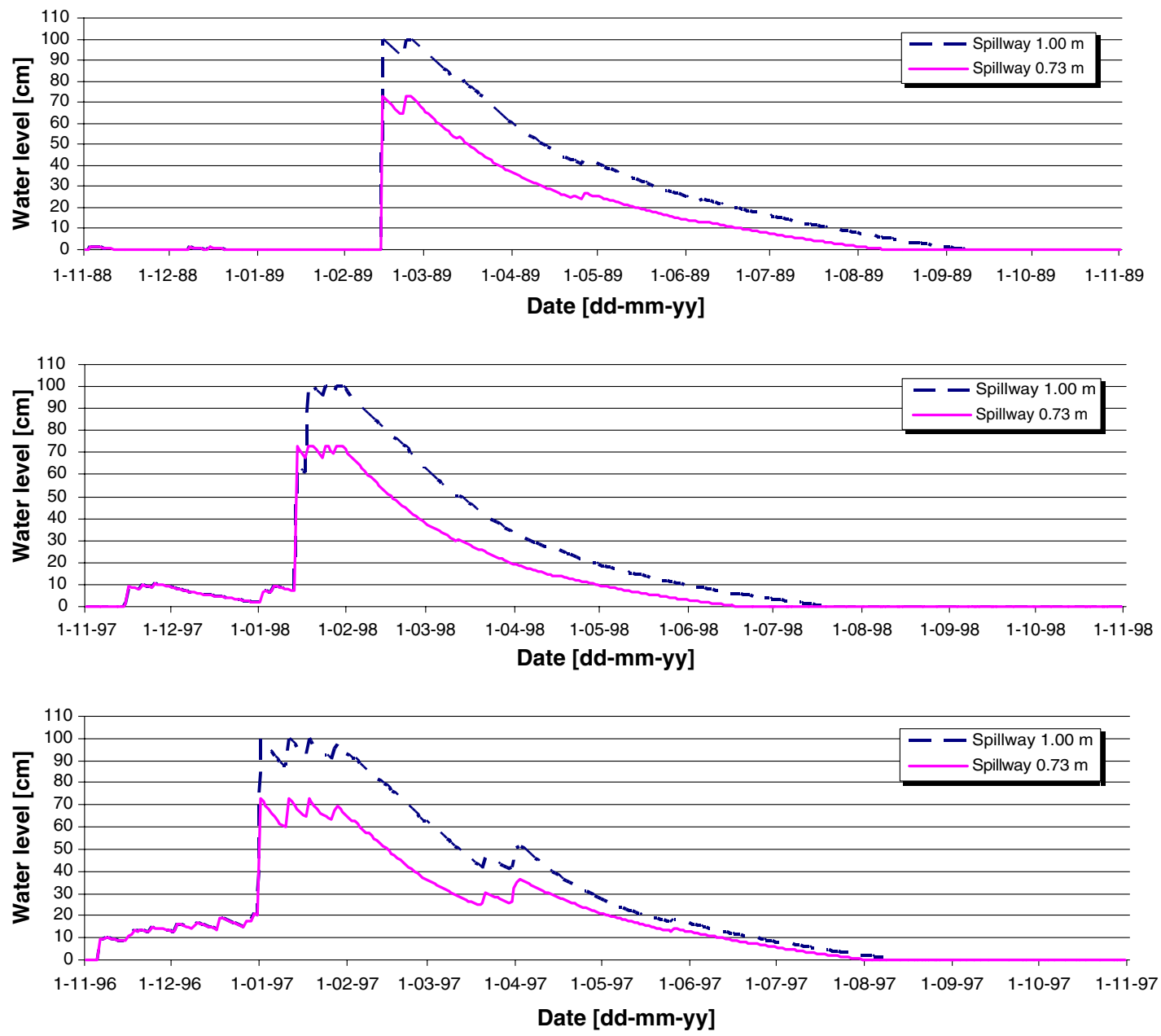

Fig. 4. Water level in the Mnyabezi reservoir for (a) the dry year '88/'89, (b) normal year'97/'98, and (c) wet year '96/'97.

Table 1

Potential water supply reservoir for different spillway heights; amount given in $\mathrm{m}^{3}$ and duration in months

\begin{tabular}{llll}
\hline & $\begin{array}{l}\text { Water supply } \\
\text { and period for } \\
\text { a dry year }\end{array}$ & $\begin{array}{l}\text { Water supply } \\
\text { and period for } \\
\text { a normal year }\end{array}$ & $\begin{array}{l}\text { Water supply } \\
\text { and period for } \\
\text { a wet year }\end{array}$ \\
\hline $\begin{array}{l}\text { Reservoir spillway 0.73; } \\
\text { including rainy season }\end{array}$ & $\begin{array}{l}1984 \mathrm{~m}^{3} \\
5.7 \mathrm{months}^{3}\end{array}$ & $\begin{array}{l}2424 \mathrm{~m}^{3} \\
7.0 \mathrm{months}^{3}\end{array}$ & $\begin{array}{l}3039 \mathrm{~m}^{3} \\
8.7 \mathrm{months}\end{array}$ \\
Reservoir spillway 0.73; & $1865 \mathrm{~m}^{3}$ & $1531 \mathrm{~m}^{3}$ & $2192 \mathrm{~m}^{3}$ \\
after last overflow-event & $5.4 \mathrm{months}^{3}$ & $4.4 \mathrm{months}^{3}$ & $6.3 \mathrm{month}^{3}$ \\
Reservoir spillway 1.00; & $2401 \mathrm{~m}^{3}$ & $2807 \mathrm{~m}^{3}$ & $3178 \mathrm{~m}^{3}$ \\
including rainy season & $6.9 \mathrm{months}^{3}$ & $8.1 \mathrm{month}^{3}$ & $9.1 \mathrm{month}$ \\
Reservoir spillway 1.00; & $2285 \mathrm{~m}^{3}$ & $1926 \mathrm{~m}^{3}$ & $2320 \mathrm{~m}$ \\
after last overflow-event & 6 months & $5.5 \mathrm{month}^{3}$ & $6.7 \mathrm{month}$ \\
\hline
\end{tabular}

The total water supply after the last dam overflow event from the alluvial aquifer of the Mnyabezi River in the current situation equals $123 \mathrm{~m}^{3}$. In that situation, the alluvial aquifer can provide water for only 14 days. In the situation of the sand storage dam, water is provided for a maximum of 70 days. The total potential water supply then becomes $603 \mathrm{~m}^{3}$. When the water is not used directly, but for example after 100 days, the total potential water supply is $375 \mathrm{~m}^{3}$ for a maximum period of 45 days. Table 2 provides an overview of the results of the alluvial aquifer with and without a sand storage dam.

\section{Discussion}

The results of the combined use of both water storage measures show that the period of water supply extends for 1.5-1.7 months after the reservoir dried out. This makes the total period of water supply 7.2 months in a dry year and 10.4 months in a wet year. Heightening the spillway increases this period to 8.4 (water sup-
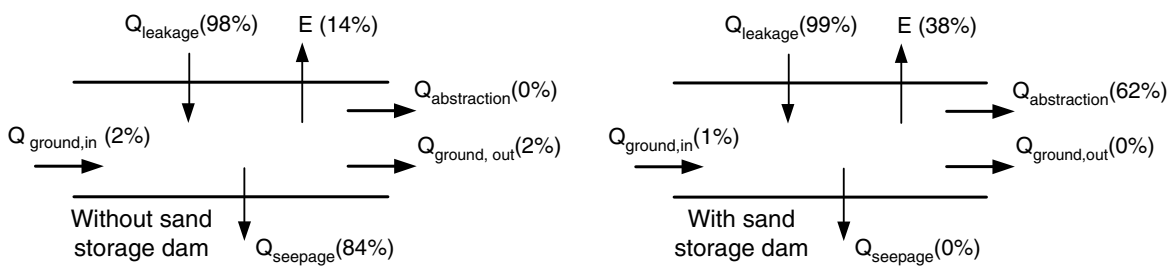

Fig. 5. Water balance alluvial aquifer for situation without (left) and with sand storage dam (right). 


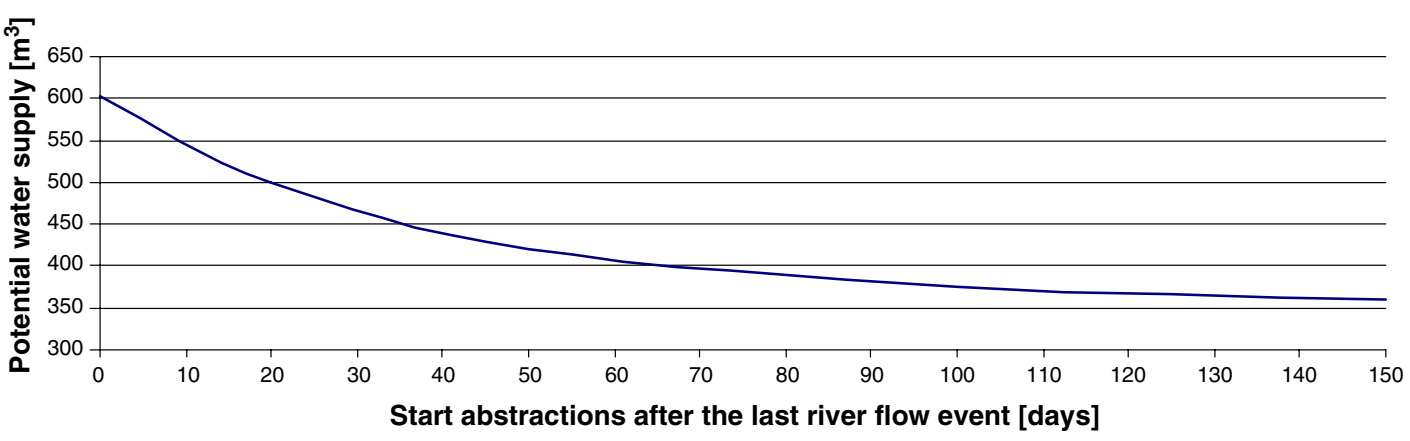

Fig. 6. Amount of water storage in the sand storage dam over time without abstractions (only loss is evapotranspiration).

Table 2

Potential water supply alluvial aquifer with and without a sand storage dam; amount given in $\mathrm{m}^{3}$ and duration in months

\begin{tabular}{|c|c|c|c|}
\hline & $\begin{array}{l}\text { Water supply } \\
\text { for a dry year }\end{array}$ & $\begin{array}{l}\text { Water supply } \\
\text { for a normal } \\
\text { year }\end{array}$ & $\begin{array}{l}\text { Water supply } \\
\text { for a wet year }\end{array}$ \\
\hline Alluvial aquifer; including & $193 \mathrm{~m}^{3}$ & $235 \mathrm{~m}^{3}$ & $242 \mathrm{~m}^{3}$ \\
\hline rainy season & 0.8 month & 1.0 month & 1.1 month \\
\hline Alluvial aquifer; 0 days & $123 \mathrm{~m}^{3}$ & $123 \mathrm{~m}^{3}$ & $123 \mathrm{~m}^{3}$ \\
\hline after last overflow-event & 0.5 month & 0.5 month & 1.5 month \\
\hline Sand storage dam; includ- & $673 \mathrm{~m}^{3}$ & $715 \mathrm{~m}^{3}$ & $800 \mathrm{~m}^{3}$ \\
\hline ing rainy season & 2.6 month & 2.8 month & 3.1 month \\
\hline Sand storage dam; 0 days & $603 \mathrm{~m}^{3}$ & $603 \mathrm{~m}^{3}$ & $681 \mathrm{~m}^{3}$ \\
\hline after last overflow-event & 2.3 month & 2.3 month & 2.5 month \\
\hline Sand storage dam; 100 days & $375 \mathrm{~m}^{3}$ & $375 \mathrm{~m}^{3}$ & $439 \mathrm{~m}^{3}$ \\
\hline after last overflow-event & 1.5 month & 1.5 month & 1.7 month \\
\hline
\end{tabular}

ply $=2776 \mathrm{~m}^{3}$ ) and 10.8 months (water supply $=3617 \mathrm{~m}^{3}$ ) respectively. Thus, there is still to bridge a gap of maximum 3.6 months and minimum 1.2 months, depending on the rainfall that year.

The rainfall-runoff model was calibrated on only one rainfall event, which causes a large uncertainty in the amount of inflow into the reservoir model. Nevertheless, the drying process of the reservoir was measured quite well. Since the aim of the study was to calculate the potential water supply after the main rainy season, the water balance results of the reservoir still provide useable outcomes. Besides, rainfall events in the semi-arid region of southern Zimbabwe are usually very heavy, which cause dam overflow in the reservoir and complete saturation of the alluvial aquifer anyway. Another large uncertainty occurs in the calculations of the water balance of the proposed sand storage dam, because the outcomes could not be verified with measured data. Nevertheless, the calculated drying time results (2-3 months) are comparable with the information obtained during field visits at similar sand storage dams in southern Zimbabwe.

\section{Conclusions}

In this study the potential water supply of the upper-Mnyabezi catchment was calculated for current conditions and after implementation of storage capacity interventions. These measures were heightening the spillway of the 'Mnyabezi 27' dam and constructing a sand storage dam in the alluvial aquifer of the Mnyabezi River. Three coupled models were used to simulate the hydrological processes in the Mnyabezi catchment: a rainfall-runoff, a reservoir and a groundwater model. The potential water supply in the Mnyabezi catchment under current conditions ranges from $2107 \mathrm{~m}^{3}$ in a dry year to $3162 \mathrm{~m}^{3}$ in a wet year and dries out after 5.7-8.7 months. After implementation of the two storage measures, there will still be a "drought gap" of maximum 3.6 months and minimum 1.2 months, depending on the rainfall that year.

For the Mnyabezi catchment the alluvial aquifer is too small to create a large storage capacity, and can only be used as an additional water recourse. However, when an ephemeral river is underlain by a larger alluvial aquifer, a sand storage dam is an efficient way of storing water in the semi-arid regions of southern Zimbabwe. An alluvial aquifer twice as large as the Mnyabezi catchment, could store between $1000 \mathrm{~m}^{3}$ and $1500 \mathrm{~m}^{3}$ water (depending on the seepage losses) for the whole year. Assuming the same domestic water use as in the Mnyabezi catchment, the sand storage dam could supply water for 4.5-7.0 months. In this study, the effects of a sand storage dam were analyzed for a small catchment. The modeling methods and obtained results are usable for a better understanding of the hydrological processes in larger alluvial aquifer systems in the Mzingwane catchment (Fig. 1).

\section{Acknowledgements}

This paper contains research results from the MSc project by W. de Hamer at the University of Twente. It is a contribution to the WaterNet Challenge Program Project 17 "Integrated Water Resource Management for Improved Rural livelihoods: Managing risk, mitigating drought and improving water productivity in the water scarce Limpopo Basin", funded through the CGIAR Challenge Program on Water and Food. The cooperation of the Zimbabwe National Water Authority, ICRISAT - Bulawayo, Dabane Trust and the University of Zimbabwe has been essential and gratefully acknowledged.

\section{References}

Anderson, N.J., 1997. Modelling the sustainable yield of groundwater resource in riverbed aquifers in arid and semi-arid areas. M.Phil to Ph.D. Transfer Report, Department of Civil Engineering, University of London, London, England.

Barker, R., Molle, F., 2004. Evolution of irrigation in South and Southeast Asia. Comprehensive Assessment Research Report 4, IWMI, Colombo, Sri Lanka.

Barnes, C.J., Jacobsson, G., Smith, G.D., 1994. The diffuse recharge mechanism in the Australian arid zone. SSSA Journal 58, 31-40.

Borst, L., DeHaas, S.A., 2006. Hydrology of sand storage dams. A case study in the kiindu catchment, Kitui District, Kenya. MSc-Thesis, Vrije Universiteit. Amsterdam, The Netherlands.

Butterworth, J.A., Mugabe, F., Simmonds, L.P., Hodnett, M.G., 1999. Hydrological processes and water resources management in a dryland environment II: surface redistribution of rainfall within fields. Hydrology and Earth Systems Sciences 3, 333-343.

De Hamer, W. Love, D., Owen, R.J.S., Booij, M.J., Hoekstra, A., 2007. A Simple rainfall-runoff Model for an Ungauged Catchment using the Water Balance of a Reservoir for Calibration. In: 8th WaterNet/WARFSA/GWP-SA Symposium, Livingstone, Zambia.

Davis, S.N., 1969. Porosity and permeability of natural materials. In: De Wiest, R.J.M. (Ed.), Flow through Porous Media. Academic Press, New York, pp. 54-89.

FAO, 1991. Water Harvesting: A Manual for the Design and Construction of Water Harvesting Schemes for Plant Production. AGL/MISC/17/91, FAO, Rome, Italy.

Gorgens, A.H.M., Boroto, R.A., 1997. Limpopo River: flow balance anomalies, surprises and implications for integrated water resources management. In: Proceedings of the 8th National Hydrology Symposium, Pretoria, South Africa.

Hanson, G., 1987. Groundwater dam research and development in the Hararghe Region, In: National Water Resource Commission, Addis Abeda, Ethiopia.

Harbaugh, A.W., 2005. A16: MODFLOW-2005, the US Geological Survey modular ground-water module - the Groundwater flow process. Techniques of Water-Resources Investigations of the United States Geological Survey Book 6, Modeling Techniques, Section A: Ground Water. US Geological Survey. Washington, DC. 
Hranova, R., 2006. Diffuse pollution of water resources, In: Principles and Case Studies in the Southern African Region, Taylor and Francis Group/A.A. Balkema Publishers, Leiden.

Love, D., Twomlow, S., Mupangwa, W., van der Zaag, P., Gumbo, B., 2006. Implementing the millennium development food security goals - challenges of the southern African context. Physics and Chemistry on the Earth 31, 731-737.

Love, D., Owen, R.J.S., Uhlenbrook, S., van der Zaag, P., Moyce, W., 2007. The lower Mzingwane alluvial aquifer: managed releases, groundwater - surface water interactions and the challenge of salinity. In: 8th WaterNet/WARFSA/GWP-SA Symposium, Lusaka, Zambia.

McDonald, M.G., Harbaugh, A.W., 1988. A MODULAR THREE-DIMENSIONAL FINITE-DIFFERENCE GROUND-WATER Flow. US Geological Survey, Washington, DC.

Mansell, M.G., Hussey, S.W., 2005. An investigation of flows and losses within the alluvial sands of ephemeral rivers in Zimbabwe. Journal of Hydrology 314, 192203.

Matura, N.E., Moyce, W., Chinoda, G., 2007. Geology of the Limpopo River Basin. WaterNet Challenge Program PN17 Activity Report 11.

Morris, D.A., A.I. Johnson, A.I., 1967. Summary of hydrologic and physical properties of rock and soil materials, as analysed by the Hydrologic Laboratories of the US. Geological Survey 1948-1960. Water Supply Paper, 1839-D, US Geological Survey. Washington, DC.

Moyce, W., Mangeya, P., Owen, R., Love, D., 2006. Alluvial aquifers in the Mzingwane Catchment: their distribution, properties, current usage and potential expansion. Physics and Chemistry of the Earth 31, 988-994.

Moyo, M., 2001. Representative soil profiles of ICRISAT research sites. Soil report No. A666. Reference No. 1787/FS/5/1/57. Chemistry and Soil Research Institute. Harare, Zimbabwe.

Nash, J.E., Sutcliffe, J.V., 1970. River flow forecasting through conceptual models. Part I - A discussion of principles. Journal of Hydrology 10, 282-290.
Nord, M., 1985. Sand Rivers of Botswana, In: Results from phase 2 of the Sand Rivers Project, Department of Water Affairs, Government of Botswana, Gaborone, Botswana.

Owen, R.J., Dahlin, T., 2005. Alluvial aquifers at geological boundaries: geophysical investigations and groundwater resources, In: Groundwater and Human Development, AA Balkema Publishers, Rotterdam, pp. 233-246.

Rushton, K.R., Weller, J., 1985. Response to pumping of a weathered granite aquifer. Journal of Hydrology 80, 299-309.

Sandstrom, K., 1997. Ephemeral rivers in the tropics. Hydrological processes and water resources assessment and management: a review and pathfinder. Research Report No. 8. EPOS. Institute of Team Research, Linkoping University. Linkoping, Sweden.

Schulze, R.E; Schmidt, E.J; Smithers, J.C., 1993. SCS-SA User Manual: PC-Based SCS design flood estimates for small catchments in Southern Africa. ACRU Report No 40. University of Kwazulu Natal. South Africa.

Seely, M., Henderson, J., Heyns, P., Jacobson, P., Nakale, T., Nantanga, K., Schachtschneider, K., 2003. Ephemeral and endorheic river systems: relevance and management challenges. In: Turton, A., Ashton, P., Cloete, E. (Eds.) Transboundary Rivers, Sovereignty and Development: Hydropolitical Drivers in the Okavango River basin. Pretoria, South Africa.

Shaw, E.M., 1994. Hydrology in Practice, third ed. Routledge, Abington.

Todd, D.K., 1980. Groundwater Hydrology, second ed. John Wiley and Sons Inc, New York.

USDA-SCS, 1972. National Engineering Handbook, Section 4. Hydrology, USDA-Soil Conservation Service, Washington, DC.

USDA-SCS, 1986. Technical Release 55: Urban Hydrology for Small Watersheds, USDA-Soil Conservation Service, Washington, DC.

Wipplinger, O., 1958. Storage of Water in Sand. South West Africa Administration Water Affair Branch, Windhoek, Namibia. 